\title{
In-field measurement of soil nitrate using an ion-selective electrode
}

\author{
Kevin J. Sibley, Gordon R. Brewster, Tessema Astatkie, John F. Adsett \\ Nova Scotia Agricultural College \\ Canada \\ Paul C. Struik \\ Wageningen University \\ the Netherlands
}

\section{Introduction}

Standard laboratory methods for measurement of soil nitrate $\left(\mathrm{NO}_{3}-\mathrm{N}\right)$ use various procedures and instruments to analyze soil samples taken from the field and transported to the laboratory. Concerns with these procedures range from delays in measurement time, the high cost of soil sampling and analysis, high labour requirements, and the need to aggregate samples. With recent advances in using the ion-selective electrode, as presented in this chapter, soil $\mathrm{NO}_{3}-\mathrm{N}$ can now be measured directly, rapidly, accurately, at low cost, at a fine scale, and in real-time right in the field. This chapter describes the methodologies and procedures for how this can be done and provides experimental data and results from data analyses that validate measurements of soil $\mathrm{NO}_{3}-\mathrm{N}$ obtained with a prototype soil nitrate mapping system (SNMS) developed at the Nova Scotia Agricultural College, Truro, Nova Scotia, Canada. These advances in the in-field use of the nitrate ion-selective electrode $\left(\mathrm{NO}_{3}{ }^{-}\right.$-ISE) provide the ability for (i) assessing soil nitrate variation, (ii) linking soil nitrate variation to crop growth, (iii) developing site-specific crop management practices, and (iv) environmental monitoring of soil nitrate.

This chapter will begin with a discussion of the concerns with nitrate in the soil and environment, precision agriculture and site-specific crop management, variation in soil nitrate and its links to crop growth and yield, and issues with assessing soil nitrate variation in a field. Next will be a discussion of ion-selective electrode theory and application for measuring soil nitrate, followed by a presentation and discussion of early experiments conducted for determining electrode operating parameters to enable the electrode to be used in a soil slurry. The development and testing of the mechanical system used for soil nitrate extraction and measurement along with a description of the control sub-unit, measurement methodology, and operation of the nitrate extraction and measurement subunit (NEMS) for using the $\mathrm{NO}_{3}^{-}$-ISE in the field will be presented. And the results of experiments used to validate in-field measurements of soil $\mathrm{NO}_{3}-\mathrm{N}$ obtained with the ionselective electrode will be presented and discussed. There will be a discussion of what is 
significant about the new measurement advances presented along with some results of experiments conducted using the SNMS in wheat and carrot production systems. Finally, conclusions and recommendations for future research in this area will be made.

\subsection{Soil nitrate is an environmental issue}

In addition to the fertility needs of farmers, it is important to deal with environmental issues associated with the use of nitrogen fertilizers. As agriculture continues its best efforts to provide the world's rising population with high-quality, safe, and nutritious food, water sources contamination and associated socio-economic costs indicate a great need for precise soil fertility management practices - using the right form of fertilizer, applied at the right time and place, in the right amount, and in the right way (Power \& Schepers, 1989; Dinnes et al., 2002).

The seriousness and extent of $\mathrm{NO}_{3}^{-}$contamination of water sources and its effect on drinking water quality has been documented and discussed by many researchers in Canada, the United States, and the European Community (USEPA, 1990; Reynolds et al., 1995; Oenema et al., 1998; Henkens \& Van Keulen, 2001). As a result, policy makers are revising laws to ensure the safety of public water supplies. These include amendments to the Water Pollution Control Acts in Canada and the United States, the European Community Nitrate Directive, and the Mineral Policy in the Netherlands.

Nitrate leaching from soil into groundwater has been attributed to poor soil nitrogen management practices involving inorganic and manure fertilizer inputs (Geron et al., 1993; Campbell et al., 1994; Patni et al., 1998; Koroluk et al., 2000; Astatkie et al., 2001; Randall \& Mulla, 2001; Dinnes et al., 2002). As such, better soil nitrogen management practices, including more accurate fertilizer recommendations and placement, could help minimize the contribution by agriculture to the $\mathrm{NO}_{3}{ }^{-}$pollution problem.

\subsection{Precision agriculture and site-specific crop management}

The profitability of farmed crops can be severely affected if poor nitrogen management practices are used. Precision agriculture technology offers farmers the potential to more intensely and precisely analyze variations in numerous field conditions throughout the growing season, in association with environmental and crop response data in order to make the most sound, and site- and time- specific, management decisions possible. At the same time the public can be assured those practices are being conducted in the most environmentally friendly way (Adamchuk et al., 2004a; Bongiovanni \& Lowenberg-DeBoer, 2004; Bourenanne et al., 2004).

The inability to assess soil and plant data rapidly and inexpensively in the field, however, remains one of the biggest limitations of precision agriculture (Adamchuk et al., 2004b). In particular, the lack of a soil $\mathrm{NO}_{3}-\mathrm{N}$ measurement system is a major roadblock (Ehsani et al., 1999). If this roadblock could be overcome, a positive contribution toward improving precision agriculture technology would be made.

\subsection{Variation in soil nitrate and its links to crop growth and yield}

Soil $\mathrm{NO}_{3}-\mathrm{N}$ levels in agricultural fields, as well as other chemical and soil physical properties, exhibit high variation spatially and temporally and at different measurement scales and levels of aggregation (Heuvelink \& Pebesma, 1999). Much research has been dedicated to assessing 
and characterizing this variation to improve our understanding of the effects of soil $\mathrm{NO}_{3}-\mathrm{N}$ on crop growth and yield within agro-ecosystems (Almekinders et al., 1995).

Growing plants utilize varying amounts of soil $\mathrm{NO}_{3}-\mathrm{N}$ during different phenological (growth) stages and its availability should ideally be in response to the plant's need. In wheat, for example, the level of available soil $\mathrm{NO}_{3}-\mathrm{N}$ during early plant growth determines yield for the most part by influencing population density and the degree of stimulation of tiller fertility, spikelet initiation, and floret fertility. Soil $\mathrm{NO}_{3}-\mathrm{N}$ uptake is greatly reduced shortly after anthesis, and nitrogen is re-translocated from leaves primarily, and other vegetative organs secondarily, to the ears to meet the need of the filling grains (Simpson et al., 1983). The reduction in soil $\mathrm{NO}_{3}-\mathrm{N}$ uptake during grain filling varies with weather conditions, disease pressures, and subsequent management practices (i.e. irrigation or chemical applications) which put stress on the plants. Physiologically, soil $\mathrm{NO}_{3}-\mathrm{N}$ and crop yields are linked via nitrate uptake and its conversion into proteins and chlorophylls during plant growth (Engel et al., 1999; Schröder et al., 2000) and photosynthesis buffering against soil nitrogen deficits by an abundance of RuBP carboxylase that serves as a reserve of protein in the leaves during unfavourable weather conditions (Hay \& Walker, 1989).

The availability and distribution of $\mathrm{NO}_{3}-\mathrm{N}$ in the soil depends on many soil forming, chemical, microbial, plant growth, environmental, and management factors that influence soil crop dynamics (Addiscott, 1983; Wagenet \& Rao, 1983; Trangmar et al., 1985). Because the effects of these factors and their interactions are highly variable (Almekinders et al., 1995), they also lead to the characteristic behavior of $\mathrm{NO}_{3}-\mathrm{N}$ being highly variable within the soil.

Studying the levels of nitrogen in various plant tissues and organs at the various phenological stages simultaneously with the availability of soil $\mathrm{NO}_{3}-\mathrm{N}$, and on a fine-scale, could provide information to researchers and farmers useful for developing better site-specific nitrogen management (SSCM) practices. Collecting this information at the required sampling intensity, however, has been found to be very tedious and generally cost and time prohibitive using current methods (Engel et al., 1999; Ehsani et al., 2001; Adamchuk et al., 2004a).

\subsection{Assessing soil nitrate variation}

Geostatistical techniques have been developed to provide practical mathematical tools for assessing spatial and temporal variation, and spatial structure of soil properties including soil $\mathrm{NO}_{3}-\mathrm{N}$ (Burgess \& Webster, 1980; Webster \& Burgess, 1984; Webster \& McBratney, 1989; McBratney \& Pringle, 1999).

Research applying these tools on a field-scale, such as through SSCM-experimentation (Pringle et al., 2004), has led to the development of a multitude of methods for determining minimum soil sample spacing, sampling grid layout and cell size (Russo, 1984; Han et al., 1994; Van Meirvenne, 2003; Lauzon et al., 2005), optimum number of samples (Webster \& Burgess, 1984), sampling schemes and protocols for pre-planning experimental designs (Trangmar et al., 1985; Chang et al., 1999; Ruffo et al., 2005) and sample bulking strategies (Webster \& Burgess, 1984).

However, when using these methods for implementing precision agriculture practices related to soil nitrogen management, the "most serious obstacles" are still the need to know the spatial structure in advance and the cost of obtaining this information even though the sampling effort required is much less than for full-scale sampling (Lark, 1997; McBratney \& Pringle, 1999; Jung et al., 2006). 


\subsection{Concept of a soil nitrate mapping system}

Development of an SNMS could contribute to the advancement of precision agriculture by providing a way to quickly, accurately, and affordably collect the data necessary to analyze small-scale variation in soil nitrate in time and space while crops are being grown, thus enabling this variation to be linked to crop growth and yield. Ideally, an SNMS would automatically collect a soil sample in the field and directly measure nitrate concentration in real-time. Moreover, global positioning system (GPS) geo-referenced data could be simultaneously recorded at each sampling location to enable a nitrate map to be created for the field. An SNMS, thus, would overcome many of the impediments, roadblocks, and serious obstacles of measuring and assessing soil $\mathrm{NO}_{3}-\mathrm{N}$ variation using conventional methods in terms of sample analysis lag time, high labour requirements, and high costs as discussed above. The overall objective of the experimental work described in this chapter was to develop and validate such an advanced soil $\mathrm{NO}_{3}-\mathrm{N}$ measurement and mapping system.

\section{Attempts by others to develop methods for in-field measurement of soil nitrate}

Over the last 20 years or so, attempts to develop a real time soil $\mathrm{NO}_{3}-\mathrm{N}$ measurement system by other researchers have been based on three types of sensors: (i) ion-selective field effect transistor (ISFET), (ii) ISE, and (iii) spectrophotometer. The majority of this research work has not progressed past laboratory feasibility studies and testing in soil-bins. A brief review of these works is presented below. Details can be obtained by reviewing the cited papers directly, or the summaries contained in the comprehensive review paper recently published by Adamchuk et al. (2004a) who concluded that "sensor prototypes capable of accomplishing this task are relatively complex and still under development."

\section{1 lon-selective field effect transistor sensor based systems}

Loreto \& Morgan (1996) developed a prototype real time soil $\mathrm{NO}_{3}-\mathrm{N}$ measurement system that consisted of a soil core sampling wheel, indexing and processing table, and a data acquisition and control system. This system was quite similar to that of Adsett \& Zoerb (1991); however it used a specially developed prototype ISFET as the $\mathrm{NO}_{3}{ }^{-}$analysis instrument. In soil bin tests, correlations between ISFET measurements with a $\mathrm{NO}_{3}{ }^{-}$-ISE and laboratory colorimetric analysis measurements had an $\mathrm{R}^{2}$ between 0.65 and 0.43 , respectively. The system worked reasonably well as a first attempt, but issues with the ISFET's response characteristics and calibration drift were apparent. Work has continued focusing on the development of ISFET technology and its use in combination with novel soil extraction and flow injection analysis (FIA) systems as a potential method of real-time measurement of $\mathrm{NO}_{3}{ }^{-}$in filtered soil extracts (Birrell \& Hummel, 1997, 2000, 2001; Price et al., 2003). This work has resulted in the development of a promising combination ISFET/FIA system that gives reasonable results compared to a cadmium reduction method using a Lachat FIA (Slope 1:1, $\mathrm{R}^{2}=0.78$ ) with a measurement time ranging between $3-5 \mathrm{~s}$ (Price et al., 2003), but it is still at the laboratory level. 


\section{2 lon-selective electrode sensor based systems}

A prototype nitrate monitoring system (NMS), was developed by Adsett (1990) and Adsett \& Zoerb (1991). It used a specially designed unit for $\mathrm{NO}_{3}{ }^{-}$extraction wherein the soil was mixed with de-ionized water and then the liquid fraction was clarified before being presented to the electrode for $\mathrm{NO}_{3}{ }^{-}$measurement. Although the system functioned reasonably well as a first attempt, it had major difficulties with collecting a soil sample and obtaining a clear extractant for $\mathrm{NO}_{3}{ }^{-}$measurement on a consistent basis. This early work was the starting point from which improvements have been steadily made by Thottan et al. (1994), Thottan (1995), Adsett et al. (1999), Khanna \& Adsett (2001), and Sibley (2008) that have advanced the system to the form described below in sections 5 and 6 into a fully functioning and field-validated prototype SNMS.

As part of an investigation into the feasibility of a real time soil $\mathrm{K}$ and $\mathrm{NO}_{3}-\mathrm{N}$ mapping system, Adamchuk et al. (2002a) performed laboratory tests on four commercially available $\mathrm{NO}_{3}{ }^{-}$-ISEs to simulate the direct soil measurement technique used in an automated soil $\mathrm{pH}$ measurement system developed by Adamchuk et al. (1999, 2002b). In the laboratory, manually remoistened previously air dried soil samples were pressed into contact with the sensing membrane of each $\mathrm{NO}_{3}{ }^{-}$-ISE to determine $\mathrm{NO}_{3}{ }^{-}$concentration (liquid basis of $\mathrm{mg} \mathrm{L}^{-}$ 1 reported as ppm). These results were compared to a standard cadmium reduction laboratory analysis technique to give an indication of the accuracy of the $\mathrm{NO}_{3}{ }^{-}$-ISEs. For individual soil samples, $\mathrm{R}^{2}$ values ranging $0.38-0.63$ were obtained, depending on the ISE, while averaging of three repeated measurements yielded $\mathrm{R}^{2}$ values ranging $0.57-0.86$. It was concluded that it is feasible to use a $\mathrm{NO}_{3}{ }^{-}$-ISE for measuring soluble nitrate concentration of naturally moist soil samples, but one of the main limitations of the proposed method reported was difficulty in maintaining high quality contact between soil and electrode. It should also be noted that use of the proposed method in the field in combination with the $\mathrm{pH}$ measurement system's soil sampling mechanism would not enable the $\mathrm{NO}_{3}-\mathrm{N}$ content $\left(\mathrm{mg} \mathrm{kg}^{-1}\right)$ of the sample to be directly computed since the 'weight' (mass) of the soil sample would not be known.

\subsection{Spectrophotometer sensor based systems}

Laboratory testing and field-based experimentation of a near-infrared (NIR) spectrophotometer conducted by Ehsani et al. (1999) using soils samples spiked with ammonium sulfate, ammonium nitrate, and calcium nitrate (10-100 ppm) revealed that soil $\mathrm{NO}_{3}-\mathrm{N}$ could be detected with $\mathrm{R}^{2}$ ranging 0.76-0.99 using partial least squares regression with each data point being an average of 10 sub-samples. However, the calibration equation must be derived from samples taken from the same location, otherwise the analysis procedure fails. Further laboratory-based research work (Ehsani et al., 2001) using soil samples spiked with ammonium nitrate and calcium nitrate (400-3000 ppm) and a spectrophotometer equipped with a deuterated triglycine sulfate (DTGS) sensor showed that the ratio of area under the nitrate peak to area under the water peak in the mid-infrared (MIR) spectra is proportional to $\mathrm{NO}_{3}{ }^{-}$concentration $\left(\mathrm{R}^{2}=0.81\right)$, and that the analysis technique is not dependent on the time of measurement, soil type, or nitrate source. However, as the authors themselves note, the range of $\mathrm{NO}_{3}{ }^{-}$concentration in agricultural soils is usually less than $100 \mathrm{ppm}$ so the practicality of this sensing method is questionable unless a more sensitive mercury cadmium telluride (MCT) type sensor can be used.

Use of a real-time portable spectrophotometer using a multi-spectral approach has been 
investigated by Shibusawa et al. $(1999,2003)$. They reported that NIR reflectance could be used to detect soil $\mathrm{NO}_{3}-\mathrm{N}$ with an $\mathrm{R}^{2}$ of 0.50 .

Christy et al. (2003) have conducted preliminary field testing of a prototype soil reflectance mapping unit utilizing a NIR spectrophotometer for simultaneously measuring total N, total carbon, $\mathrm{pH}$, and moisture content. Results from testing in a single field indicated the system could repeatably produce clear definition of patterns in these soil parameters related to spectral reflectance with an $\mathrm{R}^{2}$ of $0.86,0.87,0.72$, and 0.82 , respectively.

\section{Ion-selective electrode theory and application for measuring soil nitrate}

The nitrate ion-selective electrode $\left(\mathrm{NO}_{3}{ }^{-}\right.$-ISE) (Fig. 1) provides a rapid and reliable method for quantitative analysis of soil nitrate. Nitrate ISEs, which are highly selective to $\mathrm{NO}_{3}{ }^{-}$ions in solution, were first used around 1967 as quick and reliable alternatives to chemical-based laboratory methods for nitrate measurement (Dahnke, 1971). The $\mathrm{NO}_{3}{ }^{-}-\mathrm{ISE}$ electrochemically generates a voltage across its organophilic membrane that varies with ionic strength (molarity) of the solution according to the Nernst equation (Morf, 1981).

$$
\mathrm{E}=\mathrm{E}_{\mathrm{o}}+\mathrm{S} \log (\mathrm{A})
$$

where $\mathrm{E}$ is the electrochemical cell potential $(\mathrm{mV}), \mathrm{E}_{0}$ is the standard potential $(\mathrm{mV})$ in a $1 \mathrm{M}$ solution, ideally a constant, $\mathrm{S}$ is the electrode slope ( $-\mathrm{mV}$ per decade of concentration), and $\mathrm{A}$ is the nitrate activity (effective concentration moles $\mathrm{L}^{-1}$ ) in the solution.

Through calibration with known standards, the logarithm of solution molarity is related to electrode output voltage to determine a linear calibration curve for determining nitrate concentration (mg L-1 or ppm) of subsequent soil samples.

Typically in the laboratory, measurement of nitrate concentration of a soil sample then proceeds by mixing together a known 'weight' (mass) of soil with a known volume of deionized or distilled water (e.g. soil:extractant ratio). After an appropriate extraction time, the extractant in the mixture is decanted from the soil particles and clarified by filtration. Then the molarity of the clarified extractant is measured with the $\mathrm{NO}_{3}{ }^{-}$-ISE. The resulting electrode voltage output is mathematically converted to concentration via the calibration curve, and subsequently to content $\left(\mathrm{mg} \mathrm{kg}^{-1}\right)$ via the soil:extractant ratio.

Many researchers over the years have studied various aspects of $\mathrm{NO}_{3}^{-}$-ISE performance (accuracy, repeatability, stability, reliability), the potential for measurement interference by other ions, solution ionic strength, and use of deionized or distilled water as an extractant, for a multitude of use conditions, and in comparison with other chemical-based laboratory methods of soil nitrate determination (Myers \& Paul, 1968; Mahendrappa, 1969; Milham et al., 1970; Onken \& Sunderman, 1970; Dahnke, 1971; Mack \& Sanderson, 1971; Yu, 1985; Sah, 1994). 


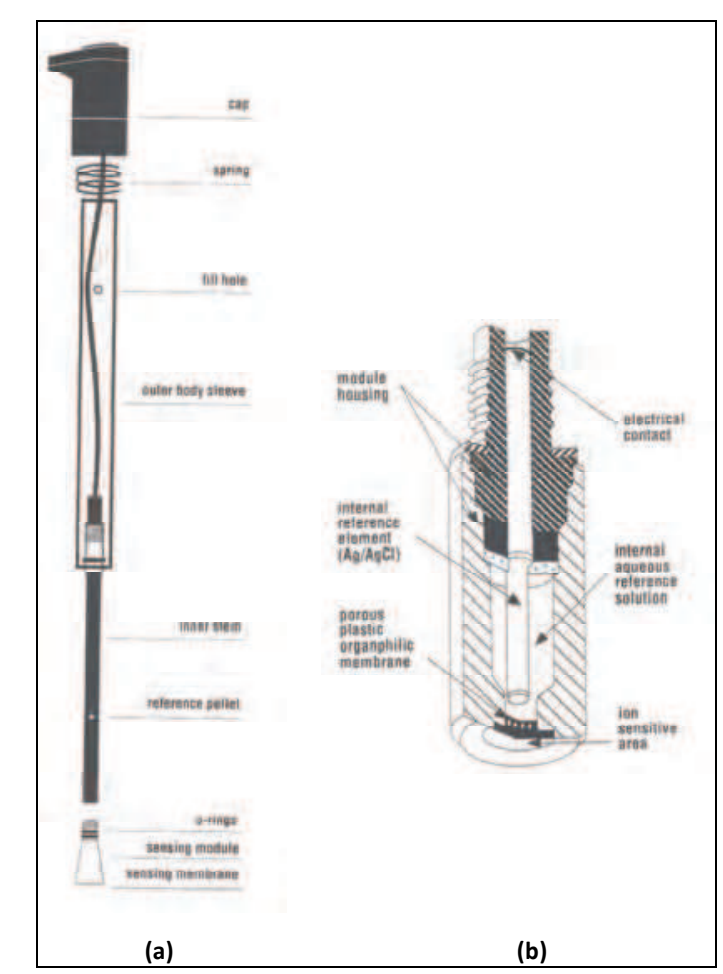

Fig. 1. The Orion 97-07 ionplus nitrate ion-selective electrode. (a) Pictorial diagram, (b) cross-section diagram of the electrode's nitrate sensing module (Orion, 2005).

As a result, $\mathrm{NO}_{3}{ }^{-}$-ISEs have enjoyed wide acceptability because the results obtained are comparable to other chemical-based methods' results, and they are quick and simple to use. Today, several types of $\mathrm{NO}_{3}{ }^{-}$-ISEs are manufactured commercially, and they are widely used in laboratories around the world for water quality monitoring and plant tissue sap nitrate measurement in addition to soil nitrate measurement. It is because of their welldefined operating characteristics, reliability, and commercial availability that a $\mathrm{NO}_{3}{ }^{-}-\mathrm{ISE}$ was chosen as the analysis instrument for the SNMS to perform direct in-field measurement of $\mathrm{NO}_{3}{ }^{-}$in a soil slurry.

\section{Experiments conducted for determining electrode operating variable parameters}

Laboratory work conducted by Thottan et al. (1994) and Thottan (1995) determined that a $\mathrm{NO}_{3}{ }^{-}$-ISE could be used in a soil slurry whilst investigating operating variables of soil:extractant ratio, slurry clarity, and electrode response time, repeatability and output signal stability.

Soil samples of sandy loam, silty clay loam, and clay loam were taken from the surface layer $(15 \mathrm{~cm})$ of fields in Cumberland and Colchester counties of Nova Scotia, Canada $\left(45^{\circ} \mathrm{N}, 63^{\circ}\right.$ $\mathrm{W})$. The results reported in this chapter relate to Chaswood clay loam, since of the three 
soils tested it is considered to be more difficult to analyze because of the higher clay content than the coarser textured soils. The Chaswood soil is of the gleysolic order, of the subgroup RegoGleysol. Particle size analysis revealed a composition of $34.0 \%$ sand, $37.9 \%$ silt, and $28.1 \%$ clay. The sampled A horizon was a fine textured alluvial formation which had been deposited above loamy sand.

Testing of the soil:extractant ratio revealed that there was no significant difference $(\alpha=0.05)$ between final $\mathrm{NO}_{3}{ }^{-}$concentrations for the three ratios tested. The mean $\mathrm{NO}_{3}{ }^{-}$concentrations determined at soil:extractant ratios of 1:15, 1:5 and 1:3 were 18.6, 18.6, and $19.3 \mathrm{ppm}$, respectively. In terms of mechanical extractor design, these results indicated that any of the three ratios may be used in the field when extracting $\mathrm{NO}_{3}{ }^{-}$from soil with equal effectiveness.

Tests to determine the effect of clarity on electrode performance showed that there was no significant difference $(\alpha=0.05)$ between mean final $\mathrm{NO}_{3}{ }^{-}$concentration measured in either slurry $(34.1 \mathrm{ppm})$, decanted $(32.0 \mathrm{ppm})$, or filtered $(33.8 \mathrm{ppm})$ soil samples. This result confirmed the hypothesis that the $\mathrm{NO}_{3}{ }^{-}$-ISE could be used in a soil slurry during in-field use-obviating the need for time consuming filtering of soil extracts required by other nitrate determination methods that would complicate mechanical system design and slow down operation. Using a $\mathrm{NO}_{3}{ }^{-}-\mathrm{ISE}$, Paul \& Carlson (1968), Myers \& Paul (1968), Dahnke (1971) and Yu (1985) also found that there was no significant difference between nitrate determinations made in a slurry or filtrate.

Fig. 2. shows a typical response curve of the $\mathrm{NO}_{3}{ }^{-}$-ISE in a soil slurry. The electrode potential drops sharply indicating a rapid release of nitrate into solution. It was found that the electrode detects a large percentage of the nitrate concentration in less than $20 \mathrm{~s}$, but it takes up to two minutes to detect the total nitrate concentration as the electrode signal stabilizes. Electrode signal stability was considered to be achieved when a signal drift of less

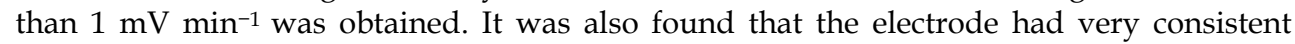
response time curves. Therefore, it was hypothesized that it was not necessary to wait until $100 \%$ of the $\mathrm{NO}_{3}^{-}$in a soil sample is extracted before taking a measurement. This characteristic was utilized to create normalized response curves (Adsett et al., 1999) to speed up the measurement cycle. Accurate and reliable estimates of the sample's total $\mathrm{NO}_{3}{ }^{-}$ concentration could be made in six seconds, which is within the time required for rapid infield measurements. A successful mechanical system, however, would depend not only on a properly functioning and calibrated electrode, but also on properly functioning mechanical components, electronics, and controls to enable it to be reliably used in the field. 


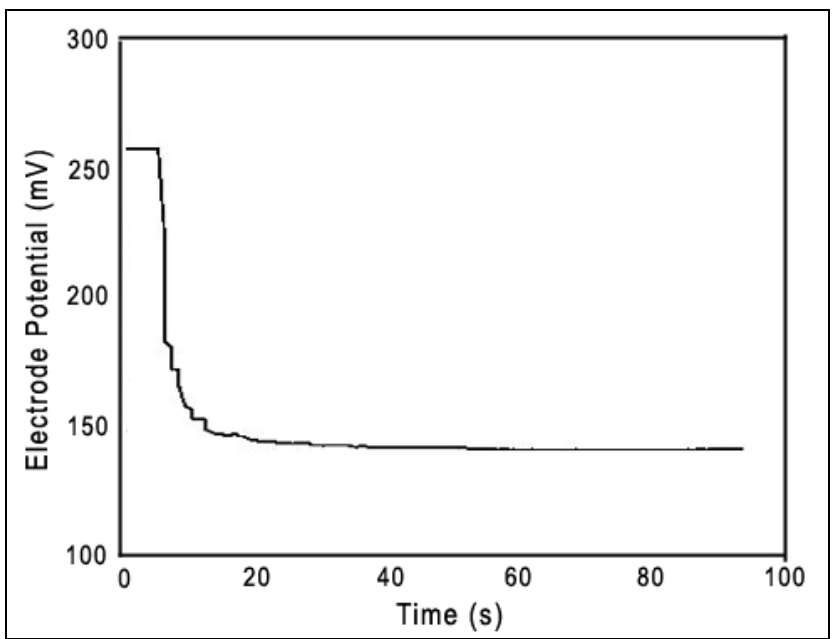

Fig. 2. Typical electrode response in soil slurry during nitrate extraction and measurement (Thottan et al., 2004).

\section{Systems developed for in-field measurement and mapping of soil nitrate}

In this section, a description of the mechanical systems and their operation for soil nitrate extraction and measurement are presented and discussed. First will be a description of the SNMS, followed by a description of the nitrate extraction and measurement sub-unit (NEMS).

\subsection{Soil nitrate mapping system}

Sibley (2008) and others (e.g.,Thottan, 1995; Adsett et al., 1999; Khanna \& Adsett, 2001) have developed a SNMS (Fig. 3) that uses a nitrate ion-selective electrode $\left(\mathrm{NO}_{3}{ }^{-}-\mathrm{ISE}\right)$ (Orion Model 9707 ionplus, Thermo Electron Corp., Massachusetts, USA) as the measurement instrument. It is an electro-mechanical machine that automatically collects a soil sample (015-cm depth), mixes it with water, and directly analyzes it electrochemically for nitrate concentration in real-time (6 s). Additionally, global positioning system (GPS) georeferenced position data are simultaneously recorded at each sampling location to enable a nitrate map to be created for the field being sampled.

The SNMS consists of six sub-units: (1) soil sampler, (2) soil metering and conveying, (3) nitrate extraction and measurement, (4) auto-calibration, (5) control, and (6) GPS as indicated in Fig 3. 


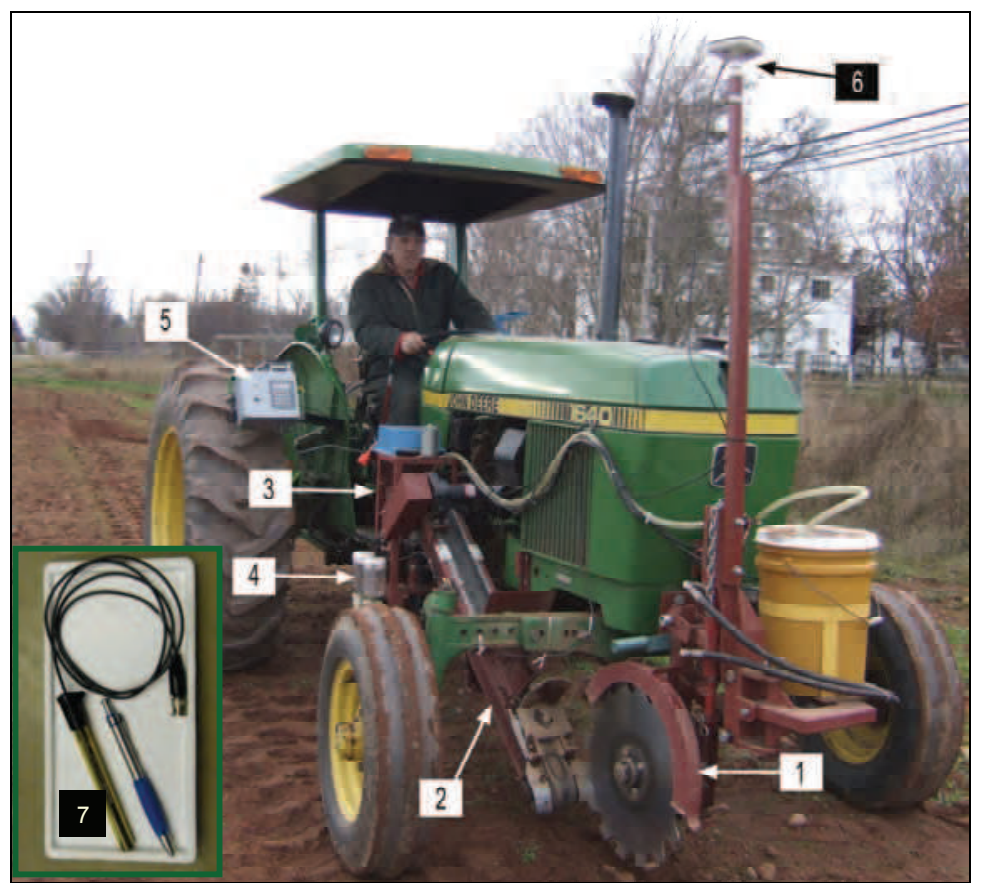

Fig. 3. Soil nitrate mapping system with six sub-units: (1) soil sampler, (2) soil metering and conveying,(3) nitrate extraction and measurement, (4) auto-calibration, (5) control and (6) global positioning system, with (7) inset showing Orion 97-07 ionplus $\mathrm{NO}_{3}{ }^{-}$-ISE used for measuring soil nitrate (adapted from Sibley, 2008).

Prior to use, the $\mathrm{NO}_{3}{ }^{-}$-ISE is calibrated using pre-prepared reagent-grade $\mathrm{NO}_{3}{ }^{-}$standards placed into the calibration cups of the auto-calibration sub-unit. As well, a field (soil condition) calibration is completed to enable rapid measurements of $\mathrm{NO}_{3}{ }^{-}$concentration to be taken during system operation. As the tractor moves forward, the SNMS collects a soil sample via the combination of soil sampler and soil metering and conveying sub-units. During sampling, the hydraulic-powered wood-saw blade is lowered into the soil by the carrying frame. Over a travel distance of approximately $0.5 \mathrm{~m}$, the blade cuts a $15-\mathrm{cm}$ deep slot and throws a spray of finely chopped soil onto the head-end area of an automatically positioned flat-belt transfer conveyer. This action creates a sample of uniform bulk density and finely-granulated particles to facilitate the subsequent nitrate extraction process (Sibley et al., 2008). The conveyor belt has an oblong fixed-volume pocket milled into its surface to collect a sample from the soil landing on the conveyor. A specially designed scraper placed above the belt levels the soil sample in the pocket without compaction and removes excess soil from the belt as the belt moves to deliver the soil sample to the NEMS. During delivery, the pocket stretches lengthwise as it passes around the conveyor's tail-end roller to facilitate complete emptying of the pocket.

Just prior to soil sample delivery, water for $\mathrm{NO}_{3}{ }^{-}$extraction is pumped into a nitrate extractor to completely submerge the sensing module of the $\mathrm{NO}_{3}{ }^{-}-\mathrm{ISE}$ and the stirrer is activated. The soil sample is received into the extractor where vigorous mixing takes place 
creating a soil slurry. Nitrate in the soil sample is rapidly extracted into the slurry. The $\mathrm{NO}_{3}{ }^{-}$ concentration of the mixture is measured by the $\mathrm{NO}_{3}{ }^{-}$-ISE and stored in the control system's computer memory. Geo-referenced position data are simultaneously recorded by the GPS sub-unit at each sampling location to enable a nitrate map to be subsequently created for the field. All data collected are downloaded to a computer for post-sampling processing via the computer-interface facility built into the control system.

The SNMS can be used to analyze soil samples automatically in real time, or manually while stationary by hand-placing samples into the NEMS. It is envisioned that two configurations of the system will eventually be used in practice-a tractor-mounted version (Fig. 3.) and a 'suitcase' (portable) version. Initial research on developing a 'suitcase version' was completed by Brothers et al., (1997). The prototype developed was capable of measuring $\mathrm{NO}_{3}{ }^{-}$and $\mathrm{pH}$ with the same mechanical system and control hardware.

\subsection{Nitrate extraction and measurement sub-unit}

The heart of the SNMS is the NEMS (Fig.4). It consists of an extractor, an impeller and drive motor, a spray nozzle, a gate valve and drive actuator, and the $\mathrm{NO}_{3}{ }^{-}-\mathrm{ISE}$. The electrode and the sample, plus associated electrode circuitry, comprise an electrochemical cell. The extractor was constructed using $9.5 \mathrm{~cm}$ ID clear acrylic tubing so that the extraction process could be viewed.

A $7.6 \mathrm{~cm}$ ID sliding-knife gate valve was installed to act as the bottom of the extraction chamber, forming the extraction chamber outlet. This arrangement gives a nearly fulldiameter chamber pass-through capability for efficient clean-out of each sample and prevents potential jamming by small stones or field debris that might enter the chamber with the soil sample. A $12 \mathrm{Vdc}$ linear actuator is used to open and close the valve between samples.

In normal position, the extraction chamber outlet is kept closed by the actuator. When the actuator is powered, it opens the extraction chamber outlet. The extraction chamber was electrically isolated from other components to eliminate any stray voltages that may interfere with the $\mathrm{NO}_{3}{ }^{-}$-ISE signal.

The added advantage of having the extraction chamber outlet normally closed was that the extraction chamber could be used as a storage unit for the electrode in a dilute $\mathrm{NO}_{3}{ }^{-}$ standard solution when not being used. To the lower end of the valve, a $3.5-\mathrm{cm}$ diameter polyvinyl chloride (PVC) pipe was connected. The PVC pipe provided structural support and electrical isolation for the extraction chamber, as well as being an extension of the extraction chamber outlet. 


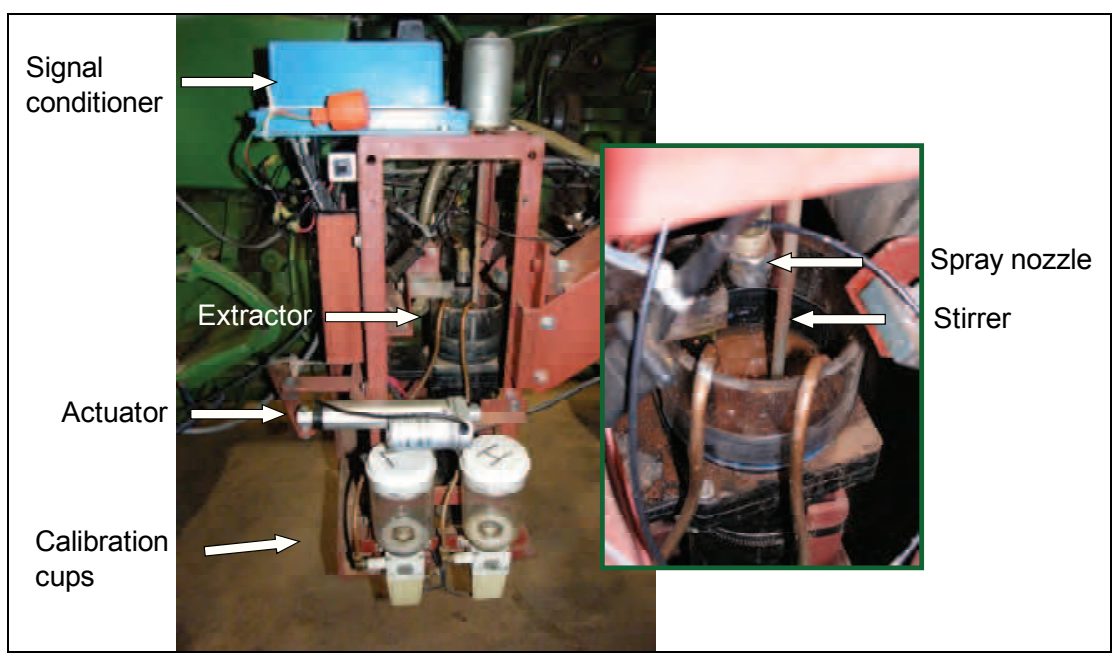

Fig. 4. Soil nitrate extraction and measurement sub-unit. Inset is a close-up view of the extractor showing a measurement being taken in a soil slurry.

A full cone spray nozzle was placed just above the extractor for supplying the water and also for cleaning purposes between successive samples. The nozzle was connected to a supply hose and a pump. A solenoid valve was fitted in between the nozzle and the pump to allow on/off flow control and also to meter in the exact amount of water under computer control by controlling the length of time the valve is turned on.

The mixing mechanism consisted of a fibreglass shaft with an acrylic impeller attached to one end. The fibreglass shaft was used in order to eliminate the possibility of any stray voltage being conducted into the extraction chamber. The shaft was powered using a variable speed $12 \mathrm{Vdc}$ motor and was operated at $300 \mathrm{rpm}$.

\section{Electronic control sub-unit, measurement methodology and operation of the nitrate extraction and measurement sub-unit}

Development of the control sub-unit to operate the $\mathrm{NO}_{3}{ }^{-}$-ISE within the NEMS and the dirty, electrically noisy environment of an agricultural tractor required development of significant advances in instrumentation signal conditioning and processing circuitry. These advances are discussed in this section.

\subsection{Electronic control sub-unit}

A schematic diagram of the electronic control sub-unit is shown in Fig. 5. The electronic control sub-unit consists of electronic circuitry, relays, a potentiometer, I/O ports, switches, and a key pad all housed in two electrically isolated and waterproof metal boxes. These are the control box shown in Fig. 3 and the signal conditioner box shown in Fig. 4, inside which the functions of signal processing and system control, and signal conditioning occur, respectively. The nitrate electrode sensing module generates a very small signal in $\mathrm{mV}$, which is entered as input to the signal conditioning circuitry. Before leaving the signal 
conditioner box the signal is converted to $\mathrm{mA}$ to prevent degradation as it travels along a cable to the processing circuitry contained in the control box. The heart of the processing circuitry is an EnT board (Advanced Monitoring Technologies Inc., New Brunswick, Canada) with eight analog and eight digital input ports, plus transistor and relay outputs. The BS2SX Stamp main processor and the BS2 Stamp chip are mounted in two on-board 24 pin sockets. The $\mathrm{mA}$ inputs received from the conditioning box are converted back to $\mathrm{mV}$ and then pass through A/D conversion. The digital signals are then processed by the Stamp BS2SX software program to produce a digital number which is stored in RAM. The digital number is subsequently used after data downloading for calculating the $\mathrm{NO}_{3}{ }^{-}$level represented by each electrode reading using a spreadsheet program. Each $\mathrm{NO}_{3}{ }^{-}$ measurement is accompanied by its geographic position coordinates as determined by a tractor-mounted GPS system (GBX-PRO with GPS/BCN, CSI Wireless Inc., Alberta, Canada). Sample location coordinates are stored in RAM.

The BS2SX Stamp main processor, also through the software program, controls the various mechanical components of the SNMS using $12 \mathrm{Vdc}$ output relays mounted on the EnT board with simple ON/OFF switching. These mechanical components are pumps, solenoid valves, a linear actuator, and electric motors.

\subsection{Operation of the nitrate extraction and measurement sub-unit}

The operation of the NEMS includes the following procedures:

1. Electrode $\left(\mathrm{NO}_{3}{ }^{-}-\mathrm{ISE}\right)$ Calibration

2. Field Calibration

3. Soil $\mathrm{NO}_{3}{ }^{-}-\mathrm{N}$ analysis

The electrode calibration procedure is important since the reliability of the $\mathrm{NO}_{3}{ }^{-}$ measurements depends entirely upon proper calibration of the $\mathrm{NO}_{3}{ }^{-}$-ISE. Two $\mathrm{NO}_{3}{ }^{-}$ standard solutions of known concentrations $(0.0001 \mathrm{M}$ and $0.1 \mathrm{M})$ made from reagent grade $\mathrm{KNO}_{3}$ crystals mixed with de-ionized water are used for calibration. The NEMS software provides an auto-calibration routine which performs a calibration under computer control. The electrode calibration provides the coefficients for the Nernst from which the $\mathrm{NO}_{3}{ }^{-}$ concentration is calculated. Thottan et al. (1994) and Thottan (1995) describe the calibration theory and process in detail.

Once the electrode calibration is completed, a field calibration is used to speed up the $\mathrm{NO}_{3}$ analysis time. The calibration determines a scaling factor which allows the prediction of the sample $\mathrm{NO}_{3}{ }^{-}$value (which occurs at electrode signal stability and which could take up to two minutes or more) after a short measurement time of six seconds (Thottan, 1995, Adsett et al., 1999). 


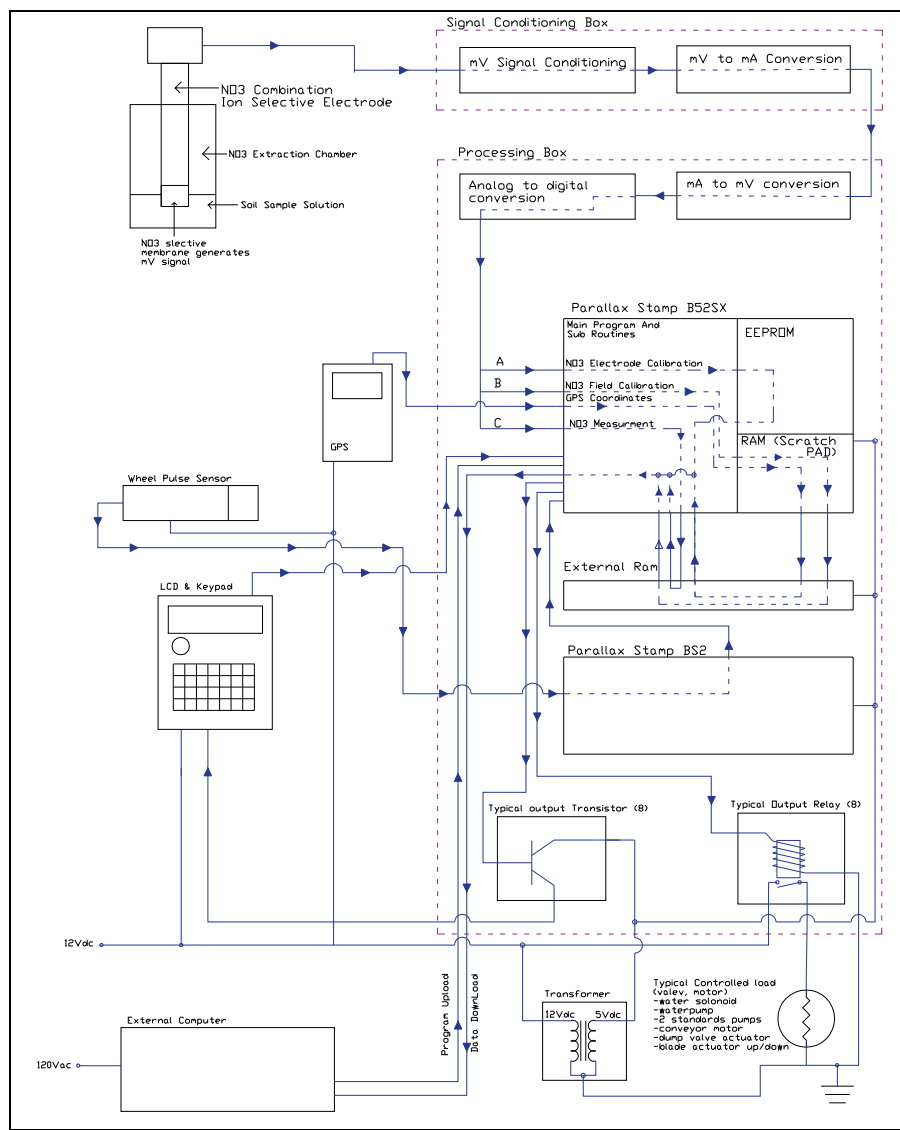

Fig. 5. Schematic diagram of the electronic control unit measurement and control circuitry, and electro-mechanical components.

The scaling factor can differ from field to field according to variations in soil characteristics, thus the name 'field calibration', and thus the necessity of the procedure. Also the field calibration is essential to monitor changes in the speed of response of the electrode's organophilic sensing membrane that have been observed with prolonged usage. A slowing of the response speed indicates it is time to change the electrode's sensing module. The time used to determine when to change the module was when it took longer than two minutes to perform a field calibration measurement. To-date, the NEMS has been used to analyze over 8,000 soil samples. And as many as 2,000 samples have been analyzed before it became necessary to change the sensing module. The membrane of the sensing modules used during this time has not showed any appreciable abrasion wear from soil particle contact.

Early work by Thottan (1994) and Thottan et al. (1999) performed a field calibration by measuring soil $\mathrm{NO}_{3}{ }^{-}-\mathrm{N}$ using a sufficient number of samples through to electrode signal stability so as to determine the response characteristics of the $\mathrm{NO}_{3}{ }^{-}$-ISE for the particular soil type in the field being sampled. Data analysis then used a statistical routine 
programmed into the control system software to determine the quickest time that resulted in a CV less than 5\% with a 95\% confidence level. The data corresponding to this time were used to calculate a scaling factor that was subsequently used to predict the final $\mathrm{NO}_{3}{ }^{-}$ concentration of a sample after measuring for this time. Six seconds always gave reliable results, and even sometimes four seconds were sufficient.

Recent work (Khanna \& Adsett, 2001; Sibley, 2008) has advanced the field measurement process even further such that a field calibration can now be based on one soil sample taken at a location considered typical of the soil texture in the field. During field calibration the $\mathrm{NO}_{3}{ }^{-}$electrode signal $(x)$ is measured at six seconds, and again at electrode signal stability (y). These $\mathrm{x}$ and $\mathrm{y}$ values are stored in Scratch Pad RAM and the scaling factor (y/x ratio) is calculated by the software program. The scaling factor is then used for prediction of the final $\mathrm{NO}_{3}{ }^{-}$value for all subsequent samples taken in that field. Following field calibration, soil samples can be collected and analyzed for $\mathrm{NO}_{3}{ }^{-}$every 40 seconds (6 seconds for $\mathrm{NO}_{3}{ }^{-}$ analysis and 34 seconds for other mechanical system functions to cycle). Sibley et al. (2009) has found this $y / x$ routine sufficient for field use. After field calibration, soil samples can be collected and analyzed for $\mathrm{NO}_{3}{ }^{-}$.

Just prior to a soil sample being deposited into the extractor, water for $\mathrm{NO}_{3}{ }^{-}$extraction is pumped into the extractor to completely submerge the electrode's sensing module and the stirrer is activated. The soil sample is deposited into the extractor where the stirrer vigorously mixes the soil slurry into which $\mathrm{NO}_{3}{ }^{-}$is rapidly extracted from the soil sample. The $\mathrm{NO}_{3}{ }^{-}$concentration of the slurry is measured by the $\mathrm{NO}_{3}{ }^{-}-\mathrm{ISE}$ and stored in the control system's computer memory. Geo-referenced position data are simultaneously recorded by the GPS sub-unit at each sampling location to enable a nitrate map to be subsequently created for the field. All data collected are downloaded to a computer for post-sampling processing via the computer-interface facility built into the control system.

\section{Experiments conducted to validate in-field measurements of soil nitrate obtained with the ion-selective electrode}

Extensive field-scale validation testing of the NEMS in two crop (wheat and carrot) production systems in Nova Scotia, Canada was conducted in 2006 (Sibley et al., 2009). Field conditions used for testing included conventional tillage vs. no tillage, inorganic vs. organic fertilization, four soil groups, and three time points throughout the season. Field moisture content ranged between $12.5-28.5 \%$.

Data was collected with the NEMS and analyzed using four data processing methods: i) integer number (IN), ii) real number (RN), iii) integer number plus moisture content correction (IN+MCC), and iv) real number plus moisture content correction (RN+MCC). Duplicate samples were also analyzed in the laboratory using standard potassium chloride $(\mathrm{KCl})$ extraction and flow injection analysis methods.

The results indicated that the level of agreement between $\mathrm{NEMS}$ soil $\mathrm{NO}_{3}-\mathrm{N}$ measurements and standard lab soil $\mathrm{NO}_{3}-\mathrm{N}$ measurements (Lab), as measured by Root Mean Squared Error (RMSE), Mean Absolute Error (MAE) and Coefficient of Efficiency (CE) was excellent. The results obtained also strongly suggest that the NEMS is quite robust and can be used for measuring soil $\mathrm{NO}_{3}-\mathrm{N}$ in both wheat and carrot crops, as well as in different soil groups, fertility levels, tillage conditions, and at any time throughout the season.

Representative graphs comparing NEMS and Lab soil $\mathrm{NO}_{3}-\mathrm{N}$ measurements over all field 
conditions tested are shown in Fig. 6. These graphs illustrate the how well the electrode performed in the field on an individual sample basis, regardless of the field condition from which the sample originated.
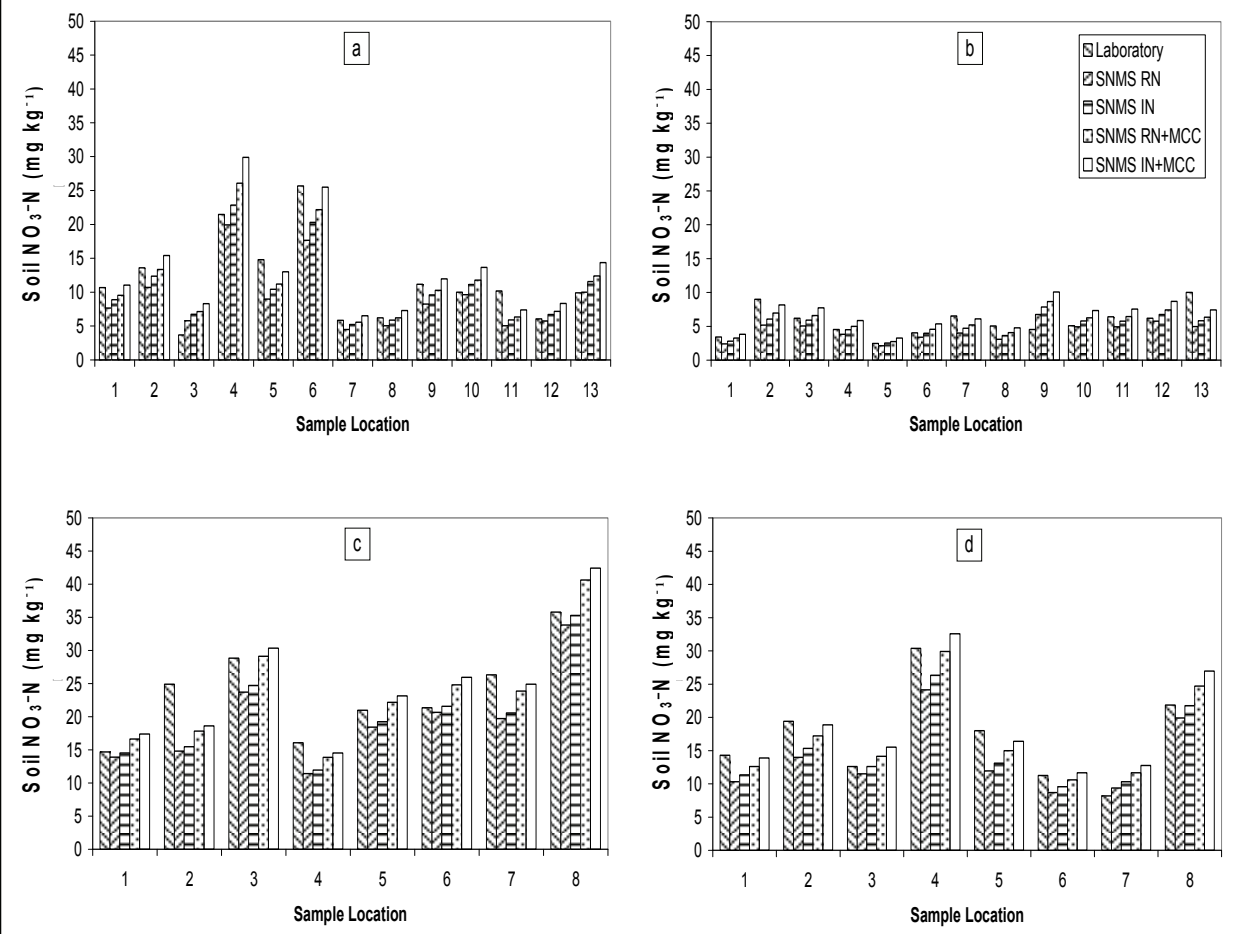

Fig. 6. Comparison of NEMS soil $\mathrm{NO}_{3}-\mathrm{N}$ measurements for each data processing method with Lab soil $\mathrm{NO}_{3}-\mathrm{N}$ measurements by sample location. (a) Wheat plot 6 (NT, DRT52) on 30 May, (b) wheat plot 8 (CT, PGW52) on 7 Nov., (c) carrot plot 2 (IF, PGW82) on 20 June and (d) carrot plot 3 (LDM, DRT22) on 7 Nov. (Sibley et al., 2009).

As well, they also indicate the responsiveness of the electrode, as the values are displayed by sampling location (x-axis) in the order of measurement. It was found that the electrode responded equally well regardless of whether the $\mathrm{NO}_{3}-\mathrm{N}$ level was changing from lower to higher, or higher to lower during measurement.

Nested linear regression analyses revealed that the NEMS had the same level of performance over all field conditions tested regardless of what data processing method was used (Sibley et al., 2009).

It was concluded that any of the regression equations developed for describing the relationship between NEMS measurements and Lab measurements for the four data processing methods tested (Fig. 7) can be used to enable field measurements of soil $\mathrm{NO}_{3}-\mathrm{N}$ using the NEMS to be obtained with lab-grade accuracy. 


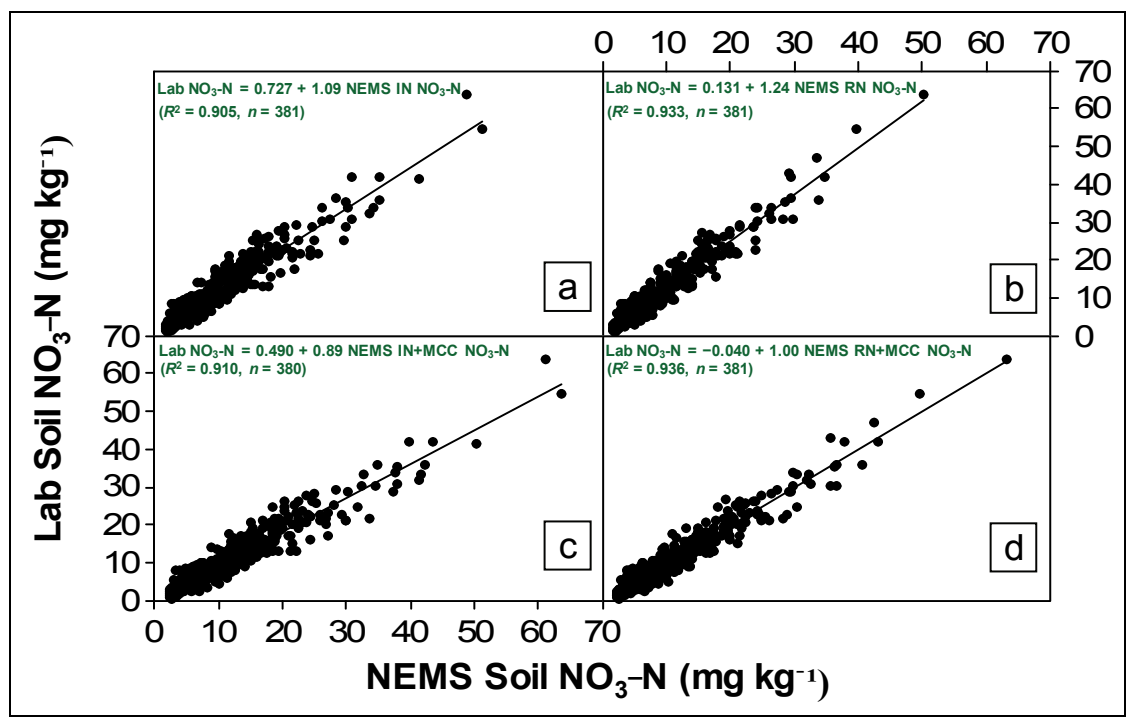

Fig. 7. Relationship between $\mathrm{NEMS}$ soil $\mathrm{NO}_{3}-\mathrm{N}$ measurements and laboratory soil $\mathrm{NO}_{3}-\mathrm{N}$ measurements for each data processing method; all field conditions data combined. (a) Integer number data processing, (b) real number data processing, (c) integer number with moisture content correction data processing and (d) real number with moisture content correction data processing (adapted from Sibley et al., 2009).

\section{Significance of the soil nitrate mapping system}

The development of the SNMS, including its NEMS, is a significant advancement in realtime field measurement of soil $\mathrm{NO}_{3}-\mathrm{N}$ from two main perspectives: (i) linking soil $\mathrm{NO}_{3}-\mathrm{N}$ variation to crop growth, and (ii) assessing soil nitrate variation. These perspectives are discussed below along with some results of experiments conducted using the system in wheat and carrot production systems in Nova Scotia, Canada.

\subsection{Linking soil nitrate variation to crop growth}

Using data collected by the NEMS on small-scale sampling grids $(6.0 \times 7.5 \mathrm{~m})$ at seven sampling dates before, during, and after crops were being grown, the variation in soil $\mathrm{NO}_{3}-$ $\mathrm{N}$ levels in wheat and carrot production systems over time were linked to crop performance (Sibley, 2008). In wheat under organic fertilizer management, the effects of conventional tillage vs. no tillage on soil nitrate, plant nitrogen and yield responses were determined. In carrot under conventional tillage management, the effects of inorganic fertilizer vs. organic fertilizer on soil nitrate, plant nitrogen and yield responses were determined.

In wheat, it was determined that the only significant difference $(\alpha=0.05)$ in mean soil $\mathrm{NO}_{3}-$ $\mathrm{N}$ level between the conventional tillage and no tillage treatments occurred early in the growing season shortly after fertilizing, when the level for the conventional tillage treatment was nearly two times higher than for the no tillage treatment (Fig. 8). 


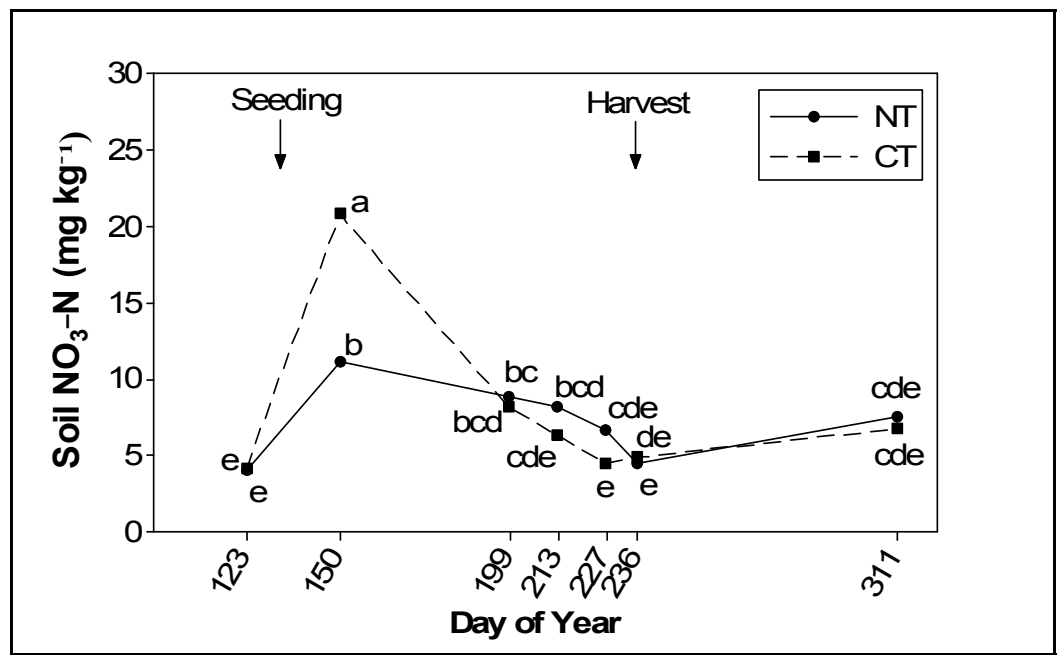

Fig. 8. Soil $\mathrm{NO}_{3}-\mathrm{N}$ response at $0-15-\mathrm{cm}$ depth to conventional tillage (CT) and no tillage (NT) treatments in the wheat field over the study period. Means sharing the same letter are not significantly different at the $5 \%$ level (Sibley, 2008).

There was no significant difference $(\alpha=0.05)$ in the response of plant tissue Total $\mathrm{N}$ to the conventional tillage and no tillage treatments; however a significant Day effect was detected. Significant differences $(\alpha=0.05)$ were found in mean tissue Total $\mathrm{N}$ level between grain set, grain filling, and maturity, but no significant difference thereafter. Mean plant tissue-sap $\mathrm{NO}_{3}-\mathrm{N}$, grain yield and grain Total $\mathrm{N}$ all showed no significant difference $(\mathrm{a}=$ $0.05)$ in response to the conventional tillage and no tillage treatments. These results suggest that the plants responded equally well at producing final grain yield under either the conventional tillage or no tillage management practice and despite there being significant changes in soil $\mathrm{NO}_{3}-\mathrm{N}$ level over the growing season.

In carrot, early in the growing season shortly after fertilizing, the soil $\mathrm{NO}_{3}-\mathrm{N}$ level for the inorganic fertilizer treatment was nearly three times higher than for the liquid dairy manure treatment, while for the remainder of the growing season it remained in the order of two times higher (Fig. 9). There was a significant $(\alpha=0.05)$ increase in soil $\mathrm{NO}_{3}-\mathrm{N}$ for both the inorganic fertilizer and liquid dairy manure treatments after harvest at the end of the study period in late-Fall. It is suspected that these late-Fall increases were due to a 'tillage effect' from mechanical harvesting in combination with a short-term increase in soil temperature typical for the geographic area. 


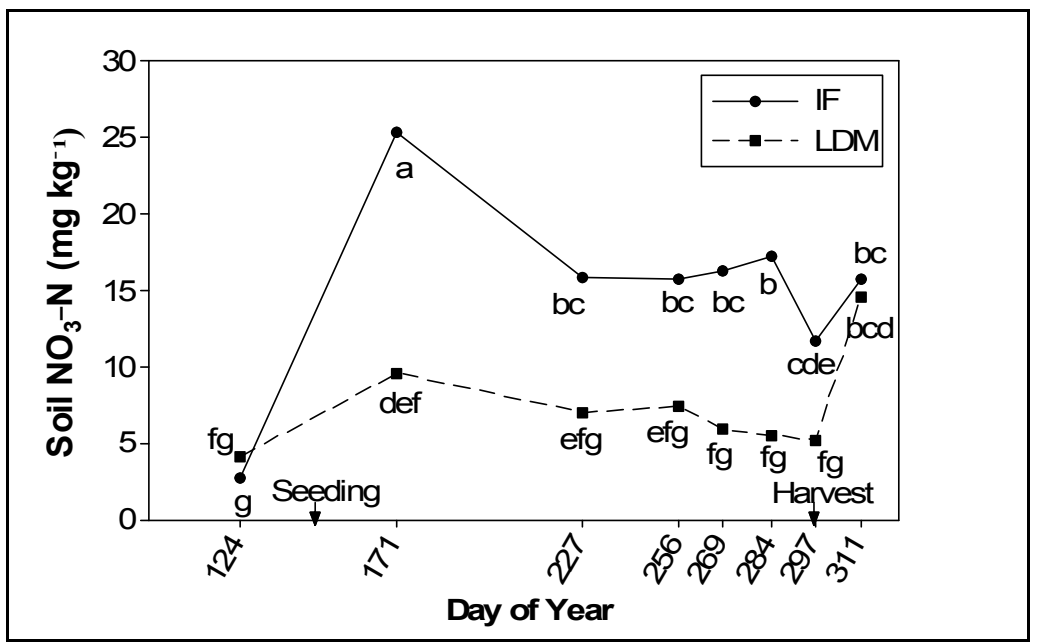

Fig. 9. Soil $\mathrm{NO}_{3}-\mathrm{N}$ response at $0-15-\mathrm{cm}$ depth to inorganic fertilizer (IF) and liquid dairy manure (LDM) treatments in the carrot field over the study period. Means sharing the same letter are not significantly different at the $5 \%$ level (Sibley, 2008).

There was no significant difference $(\alpha=0.05)$ in mean plant tissue-sap $\mathrm{NO}_{3}-\mathrm{N}$ response to the inorganic fertilizer and liquid dairy manure treatments; however a significant Day effect was detected. During mid-growth stage, plant tissue-sap $\mathrm{NO}_{3}-\mathrm{N}$ levels were sufficient for maximum top-biomass growth and root yield and then dropped off dramatically during active root bulking until homeostasis was reached. The level remained unchanged between homeostasis and the time the roots were harvested.

Plant tissue Total $\mathrm{N}$ level for the inorganic fertilizer treatment dropped significantly during active root bulking and then stabilized for the remainder of the growing season. During this same period for the liquid dairy manure treatment, tissue Total $\mathrm{N}$ level also dropped significantly $(\alpha=0.05)$, but unlike for the inorganic fertilizer treatment, continued to drop dramatically instead of stabilizing. This dramatic drop was attributed to a combination of factors including weakness of the liquid dairy manure treated plants at that time resulting in a higher rate of leaf senescence that enabled sufficient $\mathrm{N}$ re-translocation to meet the needs of the bulking roots, rainfall-induced nitrification in the soil which was limiting $\mathrm{N}$ availability to the plants, and a leaching effect of the heavy rains on the senescing leaves.

There was no significant difference $(\alpha=0.05)$ in fresh root yield or root Total $N$ between the treatments. These results suggest that the plants took up enough $\mathrm{N}$ during shoot growth to sustain root bulking, thereby utilizing stored $\mathrm{N}$ for root bulking rather than relying on available $\mathrm{N}$ in the soil. These results further suggest that although there were significant changes in soil $\mathrm{NO}_{3}-\mathrm{N}$ levels over the growing season, and between the inorganic fertilizer and liquid dairy manure treatments, they did not affect very much what was happening in the carrot plants. This finding stresses the environmental implications of managing soil $\mathrm{NO}_{3}-\mathrm{N}$ in a carrot production system. 


\subsection{Assessing soil nitrate variation}

Using data collected on a fine-scale sampling grid $(6.0 \times 7.5 \mathrm{~m})$ and a combination of classical and geostatistical analytical techniques and tools, the spatial and temporal aspects of $\mathrm{NO}_{3}-\mathrm{N}$ variation in a wheat production system at seven sampling dates covering preseeding, growing season, and post-harvest soil conditions, as well as the intrinsic spatial structure of $\mathrm{NO}_{3}-\mathrm{N}$ present in the experimental field, were assessed (Sibley, 2008).

The SNMS was successfully used to measure soil $\mathrm{NO}_{3}-\mathrm{N}$ level during the study period and to monitor spatial and temporal variation over time. As well, accurate, high resolution posted values (contour) maps were generated that give excellent visual pictures of the $\mathrm{NO}_{3}-$ $\mathrm{N}$ spatial variation that was evident just prior to, at peak nitrogen release, during, and just after the growing season (Fig. 10).

The data generated using the SNMS was also used to assess the spatial structure soil $\mathrm{NO}_{3}-\mathrm{N}$ variation in the experimental field. Very strong proportional effect relationships were found between the data sets mean and standard deviation values $\left(R^{2}=0.97\right)$ and the squared mean and variance values $\left(\mathrm{R}^{2}=0.99\right)$. These relationships can be used for predicting high-quality average and proportional variograms, which in turn can be used for determining $\mathrm{NO}_{3}-\mathrm{N}$ soil sampling schemes for the experimental field to any desired level of accuracy.

Variogram models of soil $\mathrm{NO}_{3}-\mathrm{N}$ spatial structure were developed for each of the sampling dates (Table 1). These variograms were all of the isotropic spherical type and had high $\mathrm{R}^{2}$ values ranging between $0.90-0.99$ combined with very low RSS values. These very high goodness-of-fit measures for all models indicated that they describe the spatial structure of $\mathrm{NO}_{3}-\mathrm{N}$ variation very well. Similarities in the spatial structure of soil $\mathrm{NO}_{3}-\mathrm{N}$ on the sampling dates were evident as these models had similar slopes, nuggets, ranges, and nugget-to-sill ratios. Spatial dependency was found overall to be moderate. Since the models represent data from time-spaced sampling dates, their similarity indicates a high likelihood that the intrinsic spatial structure of soil $\mathrm{NO}_{3}-\mathrm{N}$ in this experimental field exhibited temporal stability over the study period.

A scaled average variogram model that very likely accurately represents the intrinsic spatial structure present in the experimental field was created having a sill of 1.005, a nugget of 0.331 , and a range of $44 \mathrm{~m}$. This result indicates that the range of intrinsic spatial structure beyond which $\mathrm{NO}_{3}-\mathrm{N}$ values did not have spatial dependency was likely approximately 44 $\mathrm{m}$. This distance, then, would be the minimum sample spacing for conducting soil $\mathrm{NO}_{3}-\mathrm{N}$ experiments in this experimental field that require analyses by classical statistical methods. 


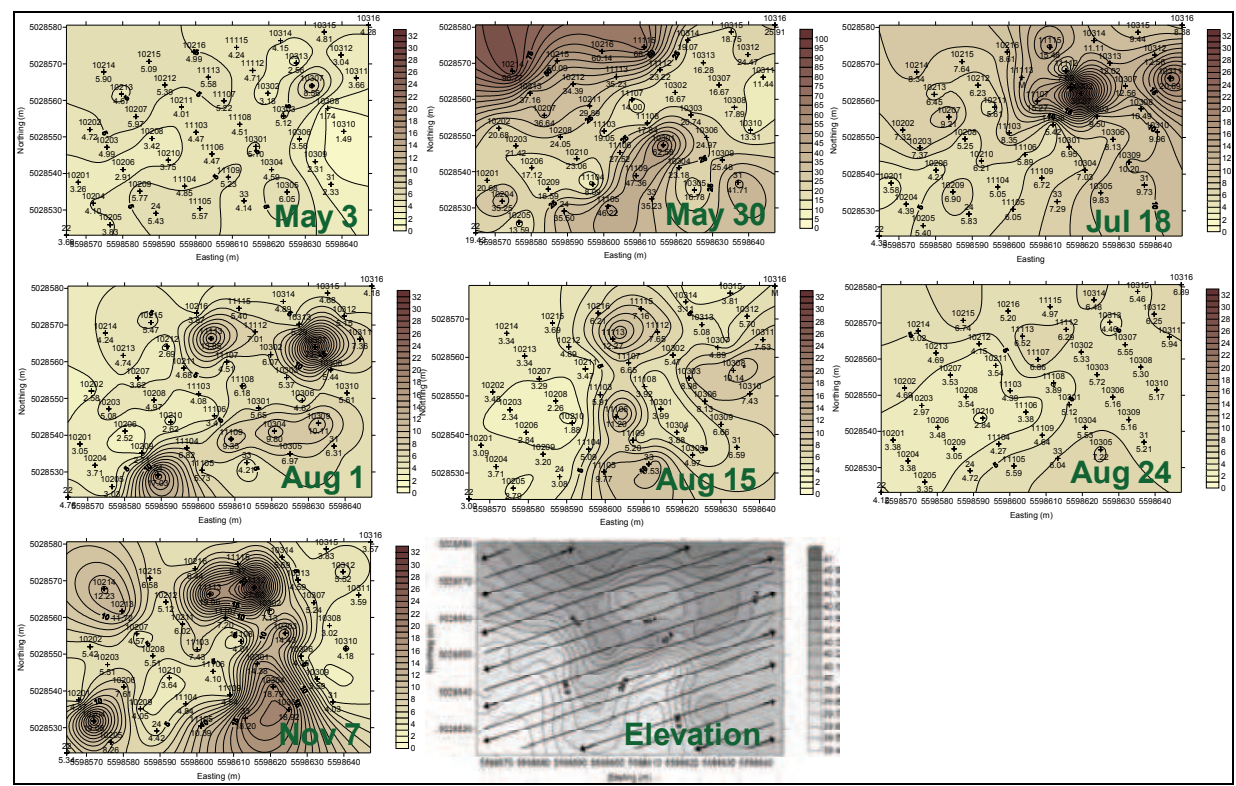

Fig. 10. Posted values isarithmic (contour) maps of soil $\mathrm{NO}_{3}-\mathrm{N}$ levels $\left(\mathrm{mg} \mathrm{kg}^{-1}\right)$ for each sampling date and a corresponding elevation map of the soil surface. Darker colour indicates higher amount of soil $\mathrm{NO}_{3}-\mathrm{N}$ or higher elevation, respectively. Note the different scale used for May 30 to enable plotting of the higher soil $\mathrm{NO}_{3}-\mathrm{N}$ levels resulting from the application of liquid dairy manure two weeks prior. May 3 is prior to field work. Aug 24 is the harvest date. Nov 7 is post-harvest (adapted from Sibley, 2008).

Being able to collect and analyze samples on a fine-scale sampling grid much quicker, as accurately as, and more affordably than conventional laboratory methods means, in practical terms, that the SNMS can provide a long-awaited solution to the problem of conducting soil $\mathrm{NO}_{3}-\mathrm{N}$ variation assessment experiments at an affordable cost. Moreover, the SNMS provides a way to collect data so that the spatial structure of the $\mathrm{NO}_{3}-\mathrm{N}$ in a field of interest is "known in advance" of the experimental planning. With this knowledge, the experimental sampling scheme and optimal sample size required for statistical analysis reliability can be determined apriori with confidence. 


\begin{tabular}{|c|c|c|c|c|c|c|c|}
\hline $\begin{array}{l}\text { Parameter/ } \\
\text { Date }\end{array}$ & 3 May & 30 May & 18 July & 1 Aug. & 15 Aug. & 24 Aug. & 7 Nov. \\
\hline Nugget, $C_{o}$ & 0.397 & 0.510 & 0.291 & 0.367 & 0.457 & 0.304 & 0.396 \\
\hline Sill, $C_{o}+C$ & 1.031 & 1.162 & 0.899 & 1.311 & 1.296 & 1.084 & 1.110 \\
\hline Ranget, $\mathrm{A}_{\mathrm{o}}$ & 41 & 43 & 39 & 62 & 68 & 51 & 27 \\
\hline $\begin{array}{l}\mathrm{N}: \mathrm{S}, \mathrm{C}_{\mathrm{o}} / \\
\left(\mathrm{C}_{\mathrm{o}}+\mathrm{C}\right)\end{array}$ & 0.385 & 0.439 & 0.324 & 0.280 & 0.353 & 0.280 & 0.357 \\
\hline $\mathrm{R}^{2}$ & 0.99 & 0.95 & 0.96 & 0.90 & 0.98 & 0.99 & 0.93 \\
\hline $\operatorname{RSS}\left(\times 10^{-4}\right)$ & 1.10 & 8.67 & 6.40 & 4.36 & 6.95 & 3.70 & 6.52 \\
\hline Lag Pairs $\ddagger$ & 33-185 & 35-192 & $30-59$ & $47-232$ & $44-263$ & 35-190 & $30-167$ \\
\hline $\begin{array}{l}\text { Spatial } \\
\text { Class } \$\end{array}$ & M & $\mathrm{M}$ & M & $\mathrm{M}$ & M & M & M \\
\hline Model & Spherical & Spherical & Spherical & Spherical & Spherical & Spherical & Spherical \\
\hline
\end{tabular}

Table 1. Parameters of final selected scaled variogram models for each sampling date (Sibley, 2008).

\section{Conclusions and recommendations for future research}

\subsection{Conclusions}

The SNMS, and its NEMS, have advanced the ability of making in-field measurements of soil $\mathrm{NO}_{3}-\mathrm{N}$ by overcoming the impediments, roadblocks, and serious obstacles to measuring and assessing soil $\mathrm{NO}_{3}-\mathrm{N}$ variation using conventional methods in terms of sample analysis lag time, high labor requirements, and high costs. It has been demonstrated that soil $\mathrm{NO}_{3}-\mathrm{N}$ measurements using the SNMS can be obtained rapidly, on a fine scale, and with lab-grade accuracy. It has been demonstrated that data collected using the SNMS can be used for assessing the spatial and temporal aspects of soil $\mathrm{NO}_{3}-\mathrm{N}$ variation, to assess variation in soil $\mathrm{NO}_{3}-\mathrm{N}$ levels in space and over time, and link this variation to crop performance.

The SNMS offers the potential to assist farmers and researchers with developing sitespecific soil nitrate management practices for agricultural production. It offers farmers the potential to more intensely and precisely analyze variations in soil $\mathrm{NO}_{3}-\mathrm{N}$ levels throughout the growing season in association with environmental and crop response data in order to make the most sound and site- and time-specific management decisions possible. As well for farmers, it offers the potential for them to measure and document soil $\mathrm{NO}_{3}-\mathrm{N}$ levels in their fields thus improving traceability and their ability to be compliant with any current and future legislation requiring control of nitrogen fertilizers. It offers regulators the potential to conduct environmental monitoring of $\mathrm{NO}_{3}^{-}$levels in agricultural fields and water sources. Ultimately as a result of its use, the public may be assured that soil nitrogen management practices in agriculture are being conducted in the most environmentally friendly way. 


\subsection{Recommendations for further research}

Since the beginning of precision agriculture, it has been a goal of many researchers and farmers to develop real-time responding variable rate (VR) fertilizer spreaders. Several types of VR spreaders that use prior-determined prescription maps have been developed and are commercially available. These spreaders are useful to a certain degree, but the missing link to their full effectiveness is still the ability to vary fertilizer application rate in response to precisely what the plant needs in real-time; particularly in response to the plant's need for nitrate, but more generally to several nutrient needs (potassium, calcium, magnesium, etc.) as a 'package' and $\mathrm{pH}$ that determine their availability. This was the initial vision for the SNMS. Thus, it has been designed as an expandable platform technology that can be easily modified to incorporate the simultaneous use of several different types of ionselective electrodes. In the immediate term, further research should be conducted to develop the agronomic-based algorithms linking soil $\mathrm{NO}_{3}-\mathrm{N}$ availability to crop performance to enable effective real time control of a fertilizer spreader by the SNMS. In the near term, further research should be conducted in combination with plant-related experiments to begin to build in the capability of the SNMS to measure and respond to the availability of a 'soil nutrient package'.

Currently, the SNMS is a tractor-mounted version. It has been mentioned above that it is envisioned that the system will eventually be used in practice also as a 'suitcase' (portable) version. Further research should be conducted to continue development of this version of the NEMS.

As well, more research should be conducted using the SNMS to further investigate the spatial and temporal variation and spatial structure of soil $\mathrm{NO}_{3}-\mathrm{N}$ and the links between soil $\mathrm{NO}_{3}-\mathrm{N}$ variation and availability and crop growth and yield under a wide variety of field conditions and crops in different geographic regions around the world.

\section{References}

Adamchuk, V.I., M.T. Morgan, \& D.R. Ess. 1999. An automated sampling system for measuring soil $\mathrm{pH}$. Trans. ASAE 42(4):885-891.

Adamchuk, V.I., A. Dobermann, M.T. Morgan, \& S.M. Brouder. 2002a. Feasibility of on-thego mapping of soil nitrate \& potassium using ion-selective electrodes. Paper No. 02-1183, ASABE, St. Joseph, Michigan, USA.

Adamchuk, V.I., M.T. Morgan, \& D.R. Ess. 2002b. System and method for automated measurement of soil pH. US Patent No. 6,356,830.

Adamchuk, V.I., J.W. Hummel, M.T. Morgan, \& S.K. Upadhyaya. 2004a. On-the-go soil sensors for precision agriculture. Computers and Electronics in Agriculture 44:71-91.

Adamchuk, V.I., M.T. Morgan, \& J.M. Lowenberg-Deboer. 2004b. A model for agroeconomic analysis of soil pH mapping. Precision Agric. 5:111-129.

Addiscott, T.M. 1983. Kinetics and temperature relationships of mineralization and nitrification in Rothamsted soils with differing histories. J. of Soil Sci. 34:343-353.

Addiscott, T.M., A.P. Whitmore, \& D.S. Powlson. 1991. Farming, Fertilizers and the Nitrate Problem. CAB International, Wallingford, U.K.

Adsett, J. F. 1990. Automated field monitoring of soil nitrate levels. Ph.D. thesis. University of Saskatchewan, Saskatoon, Saskatchewan, Canada. 
Adsett, J. F., \& G. C. Zoerb. 1991. Automated field monitoring of soil nitrate levels. p. 326335. In: Automated Agriculture for the 21st Century. ASAE Publication No. 1191. Am. Soc. of Agricultural Engineers, St. Joseph, MI., USA.

Adsett, J.F., J.A. Thotton, \& K.J. Sibley. 1999. Development of an automated on-the-go soil nitrate monitoring system. Applied Eng. in Agric. 15(4):351-356.

Almekinders, C.J.M., L.O. Fresco, \& P.C. Struik. 1995. The need to study and manage variation in agro-ecosystems. NJAS 43:127-142.

Astatkie, T., A. Madani, R. Gordon, K. Caldwell, \& N. Boyd. 2001. Seasonal variation of nitrate-nitrogen in the soil profile in a subsurfaced drained field. Can. Biosys. Eng. 43:11-16.

Birrell, S.J., \& J.W. Hummell. 1997. p. 459-468. Multi-sensor ISFET system for soil analysis. In: J.V. Stafford (ed.) Precision Agriculture '97. Proc. Eur. Conf. on Prec. Agric., 1st. Warwick Univ. Conf. Cent., UK. 7-10 Sept. 1997. BIOS Sci. Pub. Ltd., Oxford, UK.

Birrell, S.J., \& J.W. Hummell. 2000. Membrane selection and ISFET configuration evaluation for soil nitrate sensing. Trans. ASAE 43(2):197-206.

Birrell, S.J., \& J.W. Hummell. 2001. Real-time multi-ISFET/FIA soil analysis system with automatic sample extraction. Computers and Electronics in Agriculture: 32(1):45-67.

Bongiovanni, R., \& J. Lowenberg-DeBoer. 2004. Precision agriculture and sustainability. Precision Agric. 5:359-387.

Bourennane, H., B. Nicoullaud, A. Couturier, \& D. King. 2004. Exploring the spatial relationships between some soil properties and wheat yields in two soil types. Precision Agric. 5:521-536.

Brothers, J., K. J. Sibley, \& J.F. Adsett. 1997. Automated System for Soil Nitrate Analysis. Final Project Report, Agri-focus 2000 program, Nova Scotia Department of Agriculture \& Marketing. 40pp.

Burgess, T.M., \& R. Webster. 1980. Optimal interpolation and isarithmic mapping of soil properties I: the semi-variogram and punctual kriging. 1980. Journal of Soil Science. 31:315-331.

Cambardella, C.A., T.B. Moorman, J.M. Novak, T.B. Parkin, D.L. Karlen, R.F. Turco, and A.E. Konopka. 1994. Field-scale variability of soil properties in central Iowa soils. Soil Sci. Soc. Am. J. 58:1501-1511.

Campbell, C.A., G.P. Lafond, R.P. Zentner, \& Y.W. Jame. 1994. Nitrate leaching in a Udic Haploboroll as influenced by fertilization and legumes. J. Environ. Qual. 23:195-201.

Chang, J., D.E. Clay, C.G. Carlson, D. Malo, S.A. Clay, J. Lee, \& M. Ellsbury. 1999. Precision farming protocols: Part 1. Grid distance and soil nutrient impact on the reproducibility of spatial variability measurements. Prec. Agric. 1:277-289.

Christy, C.D., P.Drummond \& D.A. Laird. 2003. An on-the-go spectral reflectance sensor for soil. Paper No. 03-1044, ASABE, St. Joseph, Michigan, USA.

Dahnke, W.C. 1971. Use of the nitrate specific ion electrode in soil testing. Soil Science and Plant Analysis, 2(2):73-84.

Dinnes, D.L., D.L. Karlen, D.B. Jaynes, T.C. Kaspar, J.L. Hatfield, T.S. Colvin, \& C.A. Cambardella. 2002. Nitrogen management strategies to reduce nitrate leaching in tile-drained Midwestern soils. Agron. J. 94:153-171.

Ehsani, M.R., S.K. Upadhyaya, D. Slaughter, S. Shafii, \& M. Pelletier. 1999. A NIR technique for rapid determination of soil mineral nitrogen. Precision Agric. 1:217-234. 
Ehsani, M.R., S.K. Upadhyaya, W.R. Fawcett, L.V. Protsailo, \& D. Slaughter. 2001. Feasibility of detecting soil nitrate content using a mid-infrared technique. Trans. ASAE 44:1931-1940.

Engel, R.E., D.S. Long, G.R. Carlson, \& C. Meier. 1999. Method of precision nitrogen management in spring wheat: I fundamental relationships. Precision Agric. 1:327338.

Geron, C. A., Danneberger, T. K., Traina, S. J., Logan, T. J., \& J.R. Street. 1993. The effects of establishment methods and fertilization practices on nitrate leaching. J. Environmental Quality. 22(1):141-147.

Han, S., J.W. Hummel, C.E. Goering, M.D. Cahn. 1994. Cell size selction for site-specific crop management. Trans. ASAE 37(1):19-26.

Hay, R.K.M., \& A.J. Walker. 1989. An introduction to the physiology of crop yield. Longman Scientific \& Technical, Longman Group UK Ltd., Essex, UK.

Henkens, P.L.C.M., \& Van Keulen, H. 2001. Mineral policy in the Netherlands and nitrate policy within the European Community. NJAS 49:117-134.

Heuvelink, G.B.M, \& E.J. Pebesma. 1999. Spatial aggregation and soil process modelling. Geoderma 89:47-65.

Jung, W.K., N.R. Kitchen, K.A. Sudduth, \& S.H. Anderson. 2006. Spatial characteristics of claypan soil properties in an agricultural field. Soil Sci. Soc. Am. J. 70:1387-1397.

Keeney, D.R., \& D.W. Nelson. 1982. Nitrogen: Inorganic forms. p. 643-709. In: A.L. Page et al. (ed.) Methods of soil analysis. Part 2. Chemical and microbiological properties. ASA, Madison, WI.

Khanna, V., \& J.F. Adsett. 2001. Automated Soil Nitrate Monitoring System and Soil Nitrogen Dynamics. Project report. Engineering Department, Nova Scotia Agricultural College, Truro, Nova Scotia, Canada. 28pp.

Koroluk, R., D.Culver, A. Lefebvre, \& T. McRae. 2000. Risk of water contamination by nitrogen. In Environmental sustainability of Canadian agriculture: report of the agri-environmental indicator project. Agriculture and Agri-Food Canada. Publication 2022/E. Ch 5.

Lark, R.M. 1997. Variation in soil conditions and crop performance. p. 127-135. In: J.V. Stafford (ed.) Precision Agriculture '97. Proc. Eur. Conf. on Prec. Agric., 1st. Warwick Univ. Conf. Cent., UK. 7-10 Sept. 1997. BIOS Sci. Pub. Ltd., Oxford, UK.

Lauzon, J.D., I.P. O’Halloran, D.J. Fallow, A.P. van Bertoldi, \& D. Aspinall. 2005. Spatial variability of soil test phosphorus, potassium, and $\mathrm{pH}$ of Ontario soils. Agron. J. 97:524-532.

Loreto, A.B., \& M.T. Morgan. 1996. Development of an automated system for field measurement of soil nitrate. Paper No. 96-1087, ASABE, St. Joseph, Michigan, USA.

Mahendrappa, M.K. 1969. Determination of nitrate nitrogen in soil extracts using a specific ion activity electrode. Soil Sci. 108(2):132-136.

Mack, A.R., \& R.B. Sanderson. 1971. Sensitivity of the nitrate-ion membrane electrode in various soil extracts. Can. J. Soil Sci. 51:95-104.

McBratney, A.B., \& M.J. Pringle. 1999. Estimating average and proportional variograms of soil properties and their potential use in precision agriculture. Precision Agric. 1:125-152.

Milham, P.J., A.S. Awad, R.E.P., \& J.H. Bull. 1970. Analysis of plants, soils and waters for nitrate by using an ion-selective electrode. Analyst. 95:751-757. 
Morf, W.E. 1981. The principles of ion-selective electrodes and of membrane transport. Elsevier Scientific Publishers Co. New York, USA.

Myers, R.J.K, \& E.A. Paul. 1968. Nitrate ion electrode method for soil nitrate nitrogen determination. Can. J. Soil Sci. 48:369-371.

Oenema, O., P.C.M. Boers, M.M. van Eerdt, B. Fraters, H.G. van der Meer, C.W.J. Roest, J.J. Schroder, \& W.J. Willems. 1998. Leaching of nitrate from agriculture to groundwater: the effect of policies and measures in the Netherlands. Environ. Pollut. 102:471-478.

Orion Research Inc. 2005. Nitrate electrode instruction manual. Laboratory Products Group, Boston, MA.

Onken, A.B., \& H.D. Sunderman. 1970. Use of the nitrate electrode for determination of nitrates in soils. Soil Sci. and Plant Analysis 1(3):155-161.

Patni, N.K., L. Masse, \& P.Y. Jui. 1998. Groundwater quality under conventional and notillage: I. Nitrate electrical conductivity and pH. J. Environ. Qual. 27:869-877.

Paul, J.L, \& R.M. Carlson. 1968. Nitrate determination in plant extracts by the nitrate electrode. J. Agr. Food Chem. 16(5):766-768.

Power, J.F., \& J.S. Schepers. 1989. Nitrate contamination of ground water in North America. Agric. Ecosyst. Environ. 26:165-187.

Price, R.R., J.W. Hummel, S.J. Birrell, \& I.S. Ahmad. 2003. Rapid nitrate analysis of soil cores using ISFETs. Trans. ASAE 46(3):601-610.

Pringle, M.J., S.E. Cook, \& A.B. McBratney. 2004. Field-Scale experiments for site-specific crop management. part I: design considerations. Precision Agric. 5 617-624.

Randall, G.W., \& D.J. Mulla. 2001. Nitrate nitrogen in surface waters as influenced by climatic conditions and agricultural practices. J. Environ. Qual. 30:337-344.

Reynolds, W.D., C.A. Campbell, C. Chang, C.M. Cho, J.H. Ewanek, R.G. Kachanoski, J.A. MacLeod, P.H. Milburn, R.R. Simard, G.R.B. Webster, \& B.J. Zebarth. 1995. Agrochemical entry into groundwater. In: The health of our soils: toward sustainable agriculture in Canada. Eds. D.F. Acton \& L.J. Gregorich. Agriculture and Agri-food Canada. Publication 1906/E. Ch 10.

Ruffo, M.L., G.A. Bollero, R.G. Hoeft, \& D.G. Bullock. 2005. Spatial variability of the Illinois soil nitrogen test: Implications for soil sampling. Agron. J. 97:1485-1492.

Russo, D. 1984. Design of an optimal sampling network for estimating the variogram. Soil Sci. Soc. Am. J. 48:708-716.

Sah, R.N. 1994. Nitrate-nitrogen determination - a critical review. Commun. in Soil Sci. and Plant Anal. 25:2841-2869.

Schröder, J.J., J.J. Neeteson, O.Oenema, \& P.C. Struik. 2000. Does the crop or the soil indicate how to save nitrogen in maize production? Reviewing the state of the art. Field Crops Research 66:151-164.

Shibusawa, S., M.Z. Li, K. Sakai, A. Sasao, H. Sato, S. Hirako, \& A. Otomo. 1999. Spectrophotometer for real-time underground soil sensing. Paper No. 99-3030, $A S A B E$, St. Joseph, Michigan, USA.

Shibusawa, S., S.W. I Made Anom, C. Hache, A. Sasao, \& S. Hirako. 2003. Site -specific crop response to temporal trend of soil variability determined by real-time soil spectrophotometer. p. 639-643. In: J. Stafford, J., and A. Werner (Eds.) Precision Agriculture, Wageningen Academic Publishers, Wageningen, the Netherlands. 
Sibley, K.J. 2008. Development and use of an Automated On-the-go Soil Nitrate Mapping System. Ph.D. Thesis, Wageningen University, Wageningen, the Netherlands. ISBN 978-908504-802-2. 172pp.

Sibley, K.J., J.F. Adsett \& P.C. Struik. 2008. An On-The-Go Soil Sampler for an Automated Soil Nitrate Mapping System. Trans. ASABE 51(6): 1895-1904.

Sibley, K.J., T. Astatkie, G. Brewster, P.C. Struik, J.F. Adsett \& K. Pruski. 2009. Field-scale Validation of an Automated Soil Nitrate Extraction and Measurement System. Precision Agric. 10(2): 162-174. DOI : 10.1007/s11119-008-9801-1.

Simpson, R.J., H. Lambers, \& M.J. Dalling. 1983. Nitrogen redistribution during grain growth in wheat (Triticum aestivum L.). Plant Physiol. 71:7-14.

Thottan, J., J.F. Adsett, K.J. Sibley, \& C.M. MacLeod. 1994. Laboratory evaluation of the ion selective electrode for use in an automated soil nitrate monitoring system. Commun. in Soil Sci. and Plant Anal. 25:3025-3034.

Thottan, J.A. 1995. Microcomputer Controlled Soil Nitrate Measurement System. M.A.Sc. Thesis, Technical University of Nova Scotia, Halifax, Nova Scotia, Canada. 182pp.

Trangmar, B.B., R.S. Yost, \& G. Uehara. 1985. Application of geostatistics to spatial studies of soil properties. p. 45-94. In: N.C. Brady (ed.) Advances in agronomy. Vol. 48. Academic Press, Inc., New York.

USEPA. 1990. National Survey of Pesticides in Drinking Water Wells. USEPA, Washington, DC, USA.

Van Meirvenne, M. 2003. Is the soil variability within the small fields of flanders structured enough to allow precision agriculture? Precision Agric. 4:193-201.

Wagenet, R.J., \& B.K. Rao. 1983. Description of nitrogen movement in the presence of spatially variable soil hydraulic properties. Agric. Water Management 6:227-242.

Webster, R., \& T.M. Burgess. 1984. Sampling and bulking strategies for estimating soil properties in small regions. Journal of Soil Science 35:127-140.

Webster, R., \& A.B. McBratney. 1989. On the Akaike Information Criterion for choosing models for variograms of soil properties. Journal of Soil Science 40:493-496.

Webster, R., \& M. Oliver. 2001. Geostatistics for environmental scientists. John Wiley \& Sons, Ltd., Chichester, West Sussex, UK. 286pp.

Yu,T.R. 1985. Applications of ion-selective electrodes in soil science. Ion-Selective Electrode Review 7:165-202. 


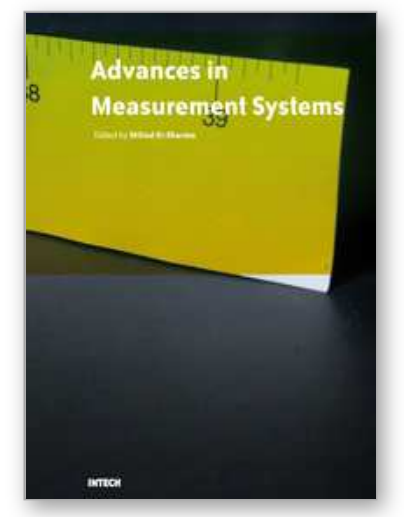

\section{Advances in Measurement Systems}

Edited by Milind Kr Sharma

ISBN 978-953-307-061-2

Hard cover, 592 pages

Publisher InTech

Published online 01, April, 2010

Published in print edition April, 2010

\section{How to reference}

In order to correctly reference this scholarly work, feel free to copy and paste the following:

Kevin J. Sibley, Gordon R. Brewster, Tessema Astatkie, John F. Adsett and Paul C. Struik (2010). In-Field Measurement of Soil Nitrate Using an Ion-Selective Electrode, Advances in Measurement Systems, Milind $\mathrm{Kr}$ Sharma (Ed.), ISBN: 978-953-307-061-2, InTech, Available from: http://www.intechopen.com/books/advancesin-measurement-systems/in-field-measurement-of-soil-nitrate-using-an-ion-selective-electrode

\section{INTECH}

open science | open minds

\section{InTech Europe}

University Campus STeP Ri

Slavka Krautzeka 83/A

51000 Rijeka, Croatia

Phone: +385 (51) 770447

Fax: +385 (51) 686166

www.intechopen.com

\section{InTech China}

Unit 405, Office Block, Hotel Equatorial Shanghai

No.65, Yan An Road (West), Shanghai, 200040, China

中国上海市延安西路65号上海国际贵都大饭店办公楼405单元

Phone: +86-21-62489820

Fax: +86-21-62489821 
(C) 2010 The Author(s). Licensee IntechOpen. This chapter is distributed under the terms of the Creative Commons Attribution-NonCommercialShareAlike-3.0 License, which permits use, distribution and reproduction for non-commercial purposes, provided the original is properly cited and derivative works building on this content are distributed under the same license. 